\title{
Melody - Usul - Poetic Prosodic Meter Relations in Ottoman-Turkish Music
}

\author{
Gözde Çolakoğlu SARI \\ İTÜ Turkish Music State Conservatory, Istanbul, Turkey
}

\begin{abstract}
Language, literature, customs and traditions, music and art are cultural items that were transmitted from generation to generation throughout history. In this context, literature is an important source of music culture that takes inspiration from the customs and traditions of a society. Prosodic meter is echoed in form, usul and general structure in works composed from the divan literature and almost lives in the work. In the same way, when examples of folk literature composed by composers and performed by poets and aşıks are examined, it is observed that there are parallels between literary features and form, structure and rhythmic features. The aim of this paper is to reveal the integral link between Melody-Usul and Meter in Ottoman Turkish Music.
\end{abstract}

Keywords: melody, usul, Aruz, Prosodic Metters, Meşk

\section{Introduction}

In this paper, it is explained the relationship of melody-usul-aruz in the Ottoman-Turkish music. Ottoman Turkish Music is the music based on meşk tradition and is transferred to today's generation through this tradition. It isn't based on any wrings ore notes. Due to this feature of meşk, storage location in the Ottoman-Turkish music education system has been the memory. The elements enhancing memory and enabling works to settle in the memory are the usul of the work and the verse of the lyrics. Usuls are composed of a combination of various rhythms and Poetic Prosodic Meter patterns are composed of a combination of various prosodic patterns. These combinations are involved as a code in the transfer of the work to the memory

\section{Melody-usul and Poetic Prosodic Metters in Ottoman Turkish Music}

Language, literature, customs and traditions, music and art are cultural items that were transmitted from generation to generation throughout history. The relationships among these items are going to be in a position of shaping the history of art. In this respect, it cannot be ignored that literature is another source of music culture that takes inspiration from the customs and traditions of a society. In terms of Turkish language and literature, it can be observed that traditional Turkish art and folk music could not be separated from the divan and folk literature.

Folk and art are considered to be the fundamental distinction in histories of all societies, however, these two types are basic parts of a whole. In the historical process, the existence of court and folk music culture in a nation have brought the result of these cultures performing the same music with different forms and instruments. A

Gözde Çolakoğlu SARI, Ph.D., associate professor, Musicology Department, İTÜ Turkish Music State Conservatory. 
similar result is also possible in terms of literature.

In this context, when examples of folk literature composed by composers and performed by poets and aşıks are examined, it is observed that there are parallels between literary features and form, structure and rhythmic features.

In the same way, poetic prosodic meter is echoed in form, usul and general structure in works composed from the divan literature and almost lives in the work. The aim of this paper is to reveal the integral link between Melody-Usul and Meter in Ottoman Turkish Music.

First, let us explain why we use the expression "Ottoman Turkish Music" for the music we refer to.

Founded in 1299, the Ottoman emirate has already become a state in the 15th century and established order. This century is a time when the various arts and sciences are trying to find their identity. In Music, theory and performance tradition from Azerbaijan, Khorasan, Samarkand, and Herat have begun living in the Ottoman society and, in particular, focus in the field of theory has shifted slowly from Turkestan and Azerbaijan until 15 Century to the Ottoman lands (Özcan, 1997, p. 473). "16 Century was a period of great improvement in the field of composing and performance and further acceleration of the shift of musical performance in the Turkish world from Turkistan, northern India, Azerbaijan to the Ottoman lands" (Özcan, 1997, p. 477). In fact, the decline period of the Ottoman Empire has been a time of major schools, composers and theorists such as the Tulip Era and III.Selim era and Turkish Music has lost all its contact with Islamic-Eastern music network and has established the identity of the Ottoman Turkish Music. The creator of this development is the reign of the Ottoman which gives value to music, the music council, theorists and composers. Because art music is also the music of the reign supported by the state and foremost the sultan.

For such reasons, we found it convenient to label the music in question as Ottoman Turkish Music in terms of its era. Today, many expressions such as Traditional Turkish Music, Turkish Maqam Music, and Turkish Music are used for this type of music. Although we consider that they might be correct in their statements, we prefer the term Ottoman-Turkish Music.

Ottoman Turkish Music is music based on meşk tradition and is transferred to today's generation through this tradition. Meşk is a term borrowed from the art of calligraphy and means "writing sample" or "writing defamation". However, this word could be used in the sense of course and learning (Behar, 1992, p. 11).

Master-apprentice, teacher-student relationship was the basis in Ottoman Turkish Music, the student has learned through the work of his teacher many times. The writing has always been on the backburner because of this feature. The letter notation which is known as ebced since joining the first letters of the Arabic alphabet and the combination of the letters corresponds to the keys and the present-day portel notation have been tried to be revived by theorists at various times, however meşk tradition of listening and the learning has surpassed writing.

In meşk method the lyrics of the studied work is written by the students or a handwritten or printed magazine is used. The usul ${ }^{1}$ of the work that will be studied is given. Before performing the work, usul is hit several times. Then the work is read by the teacher with the usul. Student repeats the work. The work is thoroughly read over and over in portions

\footnotetext{
1 The term usul, which includes both the concepts of meter (mesur) and rhythm, grew and developed out of the marriage of Ottoman-Turkish music and poetic meters (http://www.turkishmusicportal.org/page.php?id=49).
} 
(zemin, nakarat, meyan, nakarat or terennüms ${ }^{2}$ if any) and as a whole by the student until it is seated in the student's memory, this continues until the student eliminate hesitations and mistakes. Meşk is the training method of a music world where music is not put into notation or not performed with notation or some notation systems already in use were ignored. (Behar, 1992, p. 13)

Due to this feature of meşk, storage location in the Ottoman-Turkish music education system has been the memory. The elements enhancing memory and enabling works to settle in the memory are the usul of the work and the verse of the lyrics. Usuls are composed of a combination of of various rhythms and Poetic Prosodic Meter patterns are composed of a combination of of various prosodic patterns. These combinations are involved as a code in the transfer of the work to the memory.

\section{Düzüm (Rhythm)- Usul- Darb}

Düzüm (rhythm) refers to the separation of time in specific ratios, i.e., clusters of well-proportioned arranged time and usul refers to the fixed patterns composed of düzüms (Ungay, 1981, pp. 4-5). Darb ${ }^{3}$ refers to the lifting of the hand and hitting the table or the knee.

Examples of various Düzüm (Rhythm) and Usul are as follows:
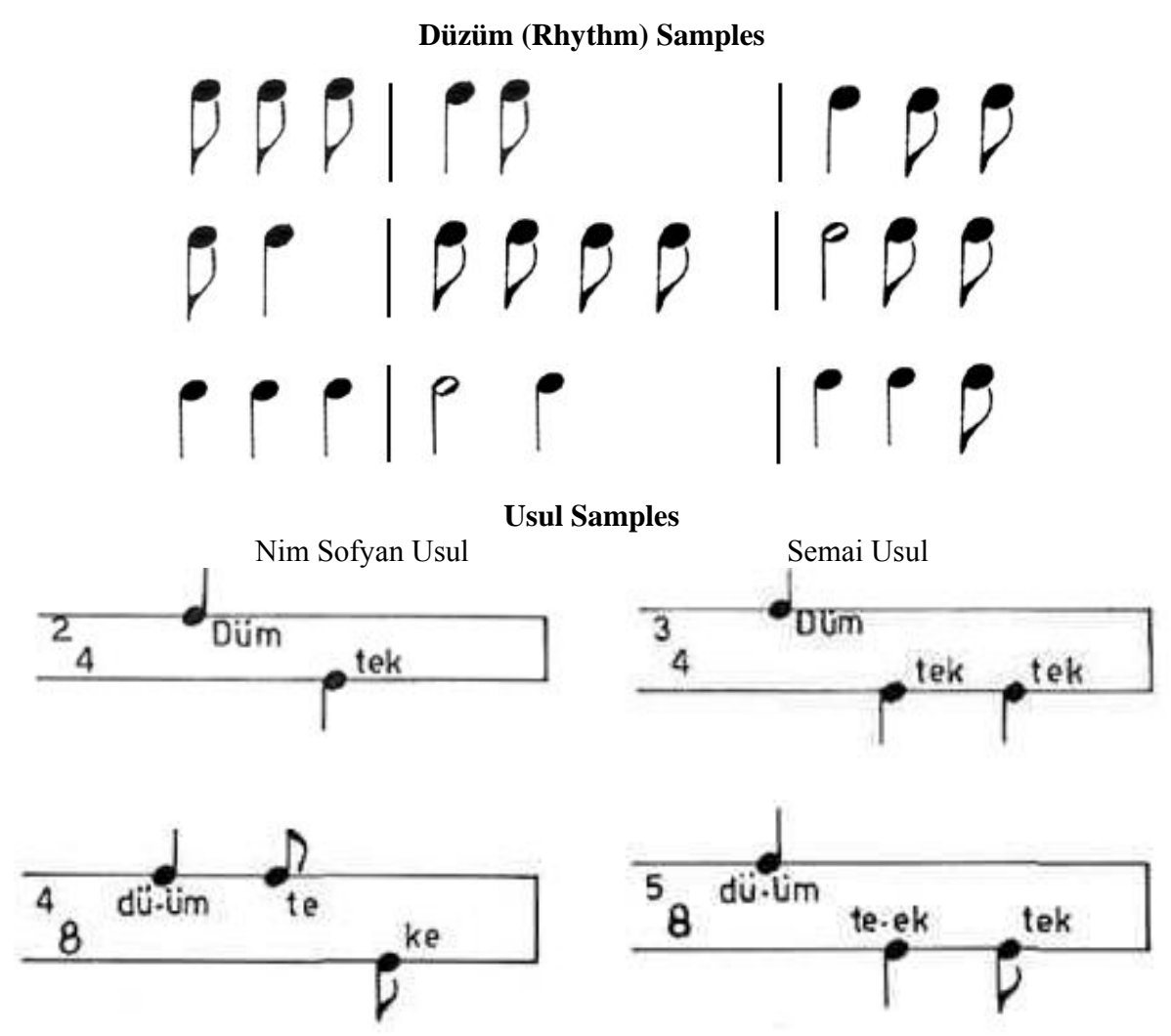

Sofyan Usul

Turkish Aksak Usul

\footnotetext{
${ }^{2}$ Terennüm which are words that complement the verses that make up the formal lyric of the song, and may either have a meaning or else be just a string or syllables, for example, rhythmical terennüm "ten, tenen, tenenen, tennenni” or verbal terennüm "canım, mirim, ömrüm".

3 The usuls are performed in beats, known in Turkish as "darp". The beats are traditionally practiced with the right and left hand striking the right and left legs. The usuls are named according to the length and form of their beats. Düm, tek, teke, tekâ, tâhek... (http://www.turkishmusicportal.org/page.php?id=49).
} 

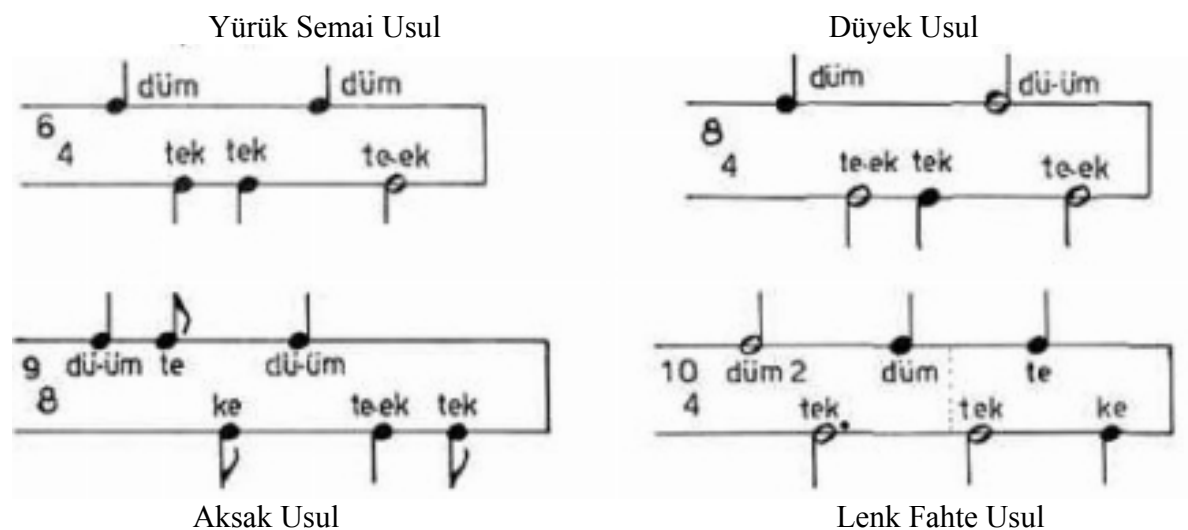

As seen in the above figures, darbs can be divided into five: düm, tek, tekâ, teke, tâhek. Usually, düm darb is strong, tekâ darb is medium strong, tek, teke ve tâhek darbs are weak. Strong and weak beats that make up each usul are different in length and number. Therefore, melodic pattern of the work is intertwined with the usul vertically. Each tune particles, each tune or each key necessarily correspond to one or more darb of a usul pattern (Behar, 1992, p. 13). In this regard, individual familiar with the usul and usul patterns takes the melody and lyrics into his memory with regions corresponding to the these darbs and his memory actually undertakes the writing of his music.

The second important element in terms of saving the work to the memory is the prosody of the lyrics as stated above. Because appropriate prosody types for each usul are known and actually usul performs the task of keeping alive the memory due combining with prosodic layers. Certain usul forms for the composition of poetic prosodic meter are combined with the internal and external rhythms of these patterns and the work. Therefore, all focal points in the works are arranged in accordance with the certain patterns of the poetic prosodic meter.

\section{Aruz (Poetic Prosodic Meter) Patterns}

Before we examine the relationship between usul patterns and Poetic Prosodic Meter Patterns with examples, we see benefits to recall basic information about Poetic Prosodic Meter: Poetic Prosodic Meter is fundamentally a dactyl based on loneness-shortness of syllables. It is known that this measure was used by the Arabs before Islam, developed by Arab linguists Imam Khalil bin Ahmed 701-775 (H.81-155) and passed to Persian after Islam (Pekin \& Karaman, 1982, p. 50).

After accepting Islam by the Turks, they learned the Arabic and Persian languages and began to write poems poetic prosodic meter. This meter was adjusted to the music of Turkish language and thus, although taken its example from the Persian Aruz, a Turkish Aruz conforming to the music of our own language is formed (Heper, 1997, p. 6).

The three important rules in the Turkish practice of Aruz are:

(1) Reading of any syllable longer in a aruz is called "imale". In fact, reading of a syllable with a closed and long vowel longer than its own voice is called "medli imale".

(2) Reading of any syllable shorter in aruz by cutting its own voice is called "zihaf".

(3) If a word beginning with a vowel comes after a word ending with a consonant in aruz utterance, the last letter of the first word is said to be connected to the first letter of of the second word and is called "vasl" or "ulama" (Meydan, 1960, p. 704). 


\section{Main Patterns}

1- Fa' û lün / Fe' û lün

$\cdot-\ldots$

2- Fâ' i lün / Fâ' i lât

3- Me fâ i lün

$\bullet-$

4- Fâ i lâ tün

5- Müs tef' i lün

6- Me fâ i lâ tü

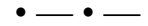

7- Mü fâ a le tün

$\bullet$

8- Mü te fâ i lün

$\bullet-\bullet-$

Various Flat Patterns

1. Fâ'il â tün / Fâ'i lâ tün / Fâ' i lün (Fâilât)

- $\cdot-\frac{1}{-} \cdot-\ldots-1-\cdot$

2. Mefâ'îlün / Me fấ î lün / Fa'û lün

$\cdot--1 \cdot--1 \cdot \cdots-$

3. Fâ'i lâ tün / Me fâ' î lün / Fa'i lün

$\cdots \ldots-1 \cdot \ldots-1 \cdot \bullet-$

4. Fa'ilâtün / Fa'i lâ tün / Fa'i lün

$\cdots--1 \cdot \cdots--1 \cdot \bullet-$

5. Fâ'ilâtün / Fâ'i lâ tün / Fâ'i lâ tün / Fâ' i lün

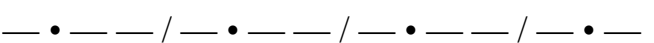

6. Me fâ ' i lün / Fa' i lâ tün / Me fâ' i lün /Fa' i lün (fa' lün)

$\bullet-\bullet-1 \cdot \bullet-\ldots-1 \cdot \ldots-1 \cdot \bullet-(\cdot-)$

7- Me fầ' î lün / Me fầ î lün / Me fâ' î lün / Me fâ' î lün

$\cdot \ldots-1 \cdot \ldots-1 \cdot \ldots-1 \cdot \ldots$

8- Mef 'û lü / Me fâ 'i lün / Fa' û lün

$-\ldots$

9- Mef 'û lü / Me fầ 'i lü / Fa' û lün

10- Mef 'û lü / Me fâ 'î lü / Me fâ ' î lü / Fa 'û lün 
$-\ldots \cdot / \cdot-\ldots \cdot / \cdot-\ldots \cdot / \cdot-\ldots$

11- Mef 'û lü / Me fâ 'î lü / Me fầ ' î lü / Fe ' û lün

-

12- Mef ' û lü / Fâ i lâ tü / Me fâ 'î lü / Fâ ' i lün

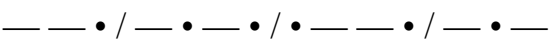

13- Müs tef i lün / Fe û lün / Müs tef i lün Fe û lün

14- Müs tef' i lün / Müs tef' i lün /Müs tef' i lün / Müs tef' i lün

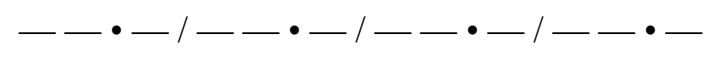

15- Müs tef'i lâ tün / Müs tef' i lâ tün / Müs tef' i lâ tün / Müs tef' i lâ tün

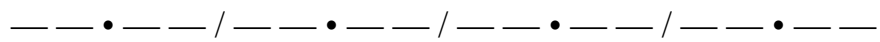

16- Müf te’i lün / Fâ i lün / Müf te' i lün / Fâ i lün

17- Müf te i lün / Müf te i lün / Fâ i lün

Let's examine the examples illustrating the relationships of usul and prosodic patterns in musical works.

1- Examinations by starting from Usul: Usul-Aruz relationship of Turkish aksak and Lenk Fahte Usul

\section{Turkish Aksak Usul and Mef û lü / Me fâ î lü / Me fâ 'î lü / Fe û lün Pattern}

One handred and fifty-two works composed with 5-time Turkish Aksak were examined by us and it has been observed that 130 have Mef û lü / Me fâ î lü / Me fâ î lü / Fe û lün, 10 have Müs tef i lâ tün / Müs tef i lâ tün / Müs tef i lâ tün / Müs tef i lâ tün / Müs tef i lün, 7 have Müs tef i lün /Müs tef i lün / Müs tef i lün, 2 have Mef û lü/ Me fâ i lün/ Fe û lün and 3 have Fâ i lâ tün / Fâ i lâ tün/ Fâ i lün pattern.

Below is an analysis of prosody, meter, and unit value of Hejaz Ode by Haci Arif Bey who is a composer famous for his use of Turkish aksak.
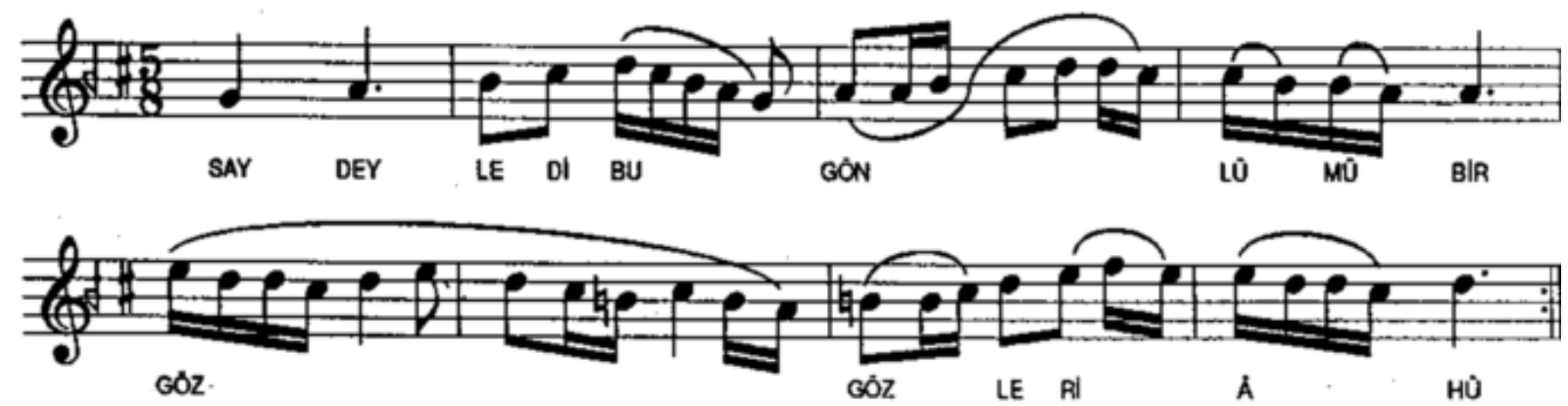

Say dey le di bu gön lü mü bir göz le ri â hû (1. misra)

Mef û lü / Me fầ î̉ / Me fâ î lü / Fe û lün 


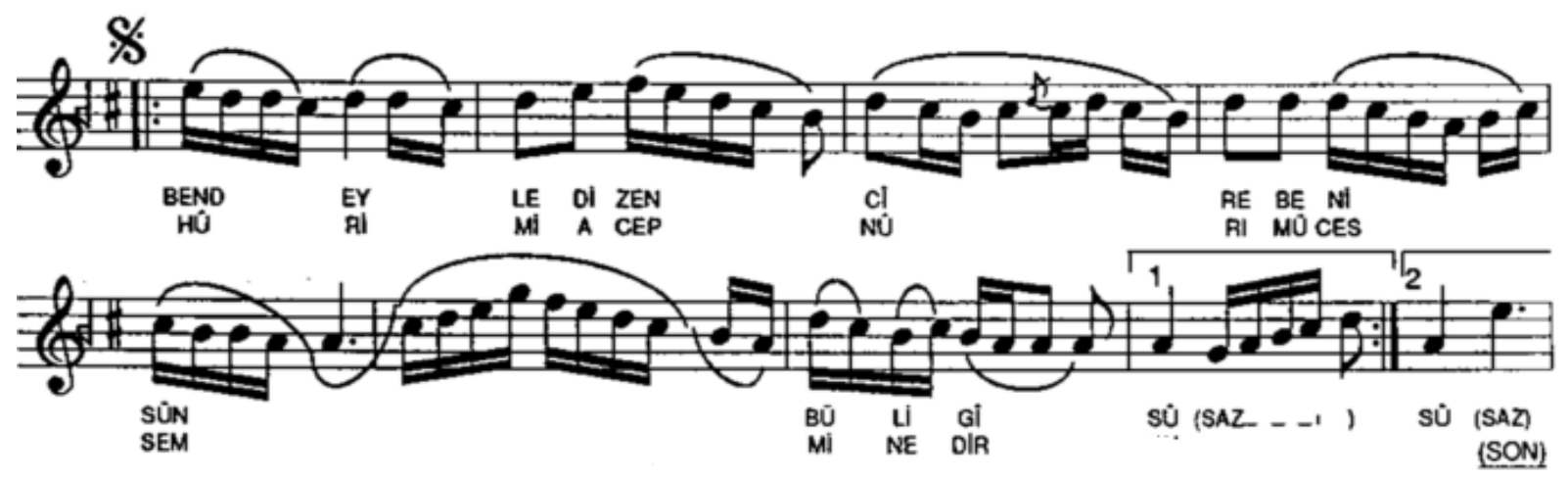

Ben dey le /di zin cî re be nî sün bü li gî sû (2.line)

- _ • $/ \cdot \cdot-\ldots$

Mef û lü / Me fâ î lü / Me fâ î lü / Fe û lün

The lyrics of this work consist of four verses. As each verse is being completed in 8 meters, each prosodic pattern is being completed within 8 meters. The same rhythm patterns are covered by the same rhythmic movements in four verses, rhythmic values taken by prosodic patterns in the ongoing work are in the same way throughout the work, synchronized usul and prosody in question show itself throughout the work. Aruz patterns corresponding to the unit values are as follows:
1. Meter
Mef û
2. Meter
3. Meter
4. Meter
lü / Me fâ
$\hat{1}$
lü / Me fâ
5. Meter
dod.

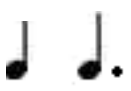
dod.

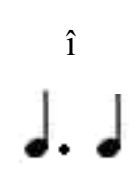
6. Meter
7. Meter
8. Meter
d.
lü/
$\mathrm{Fe}$ û
lü
d. .
d. Do
d. .

\section{Lenk Fahte Usul and Müstef i lün / Fe û lün/ Müstefilün/ Fe û lün Pattern}

It has been observed that Müstef' i lün / Fe û lün/ Müstefilün/ Fe û lün pattern was used in the works composed by 10-time Lenk Fahte usul. Below is a prosody, meter and unit analysis of Hicazkar Nakış by Zekai Dede.
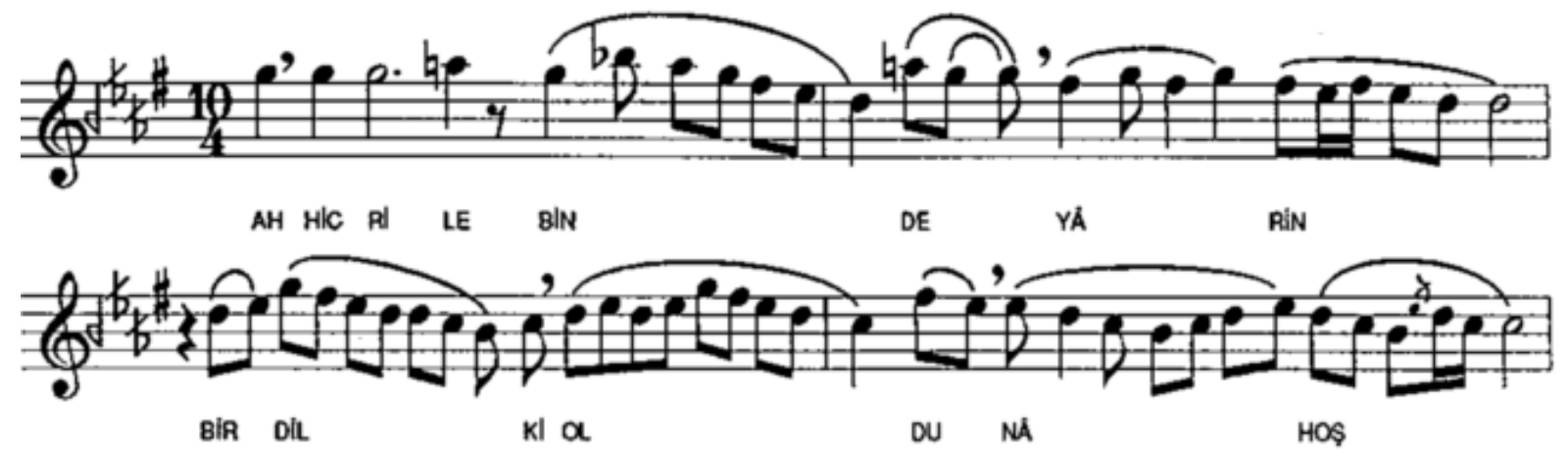

Hic rî le bin de yâ rin bir dil ki ol du nâ hoş (1. misra)

Müs tef i lün Fe û lün Müs tef i lün Fe û lün 

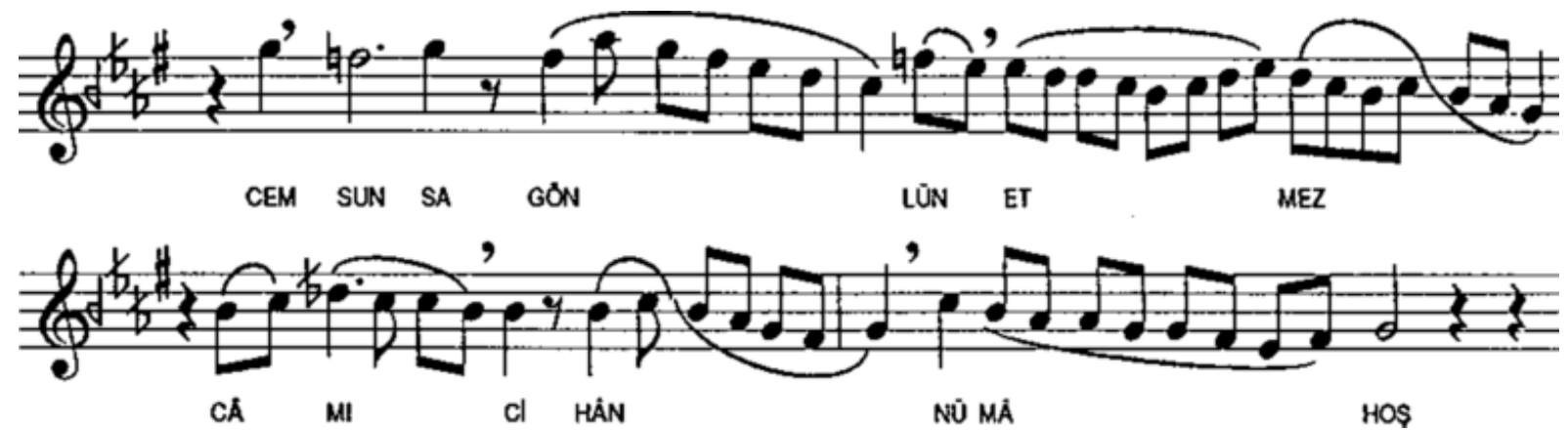

Cem sun sa gön lü net mez câm î ci hân nü mâ hoș (2. verse)

- — - - $1 \cdot-\ldots-1 \ldots$

Müs tef i lün Fe û lün Müs tef i lün Fe û lün

The lyrics of this work consist of four verses. As each verse is completed in four meter, each prosodic pattern is completed in four sizes. Each pattern of the prosody consisting of four patterns as Müs tef i lün $\mathrm{Fe}$ û lün/ Müs tef i lün/ Fe û lün were placed in a meter, only $1 / 4(d)$ value was removed to the next measurement. The reason for this situation is $1 / 4\left(\frac{z}{2}\right)$ rest at the beginning of the work. This sign has led to a subsequent measure to overflow up to a meter of $1 / 4$ throughout the work. Rhythmic values taken by prosodic patterns continue in the same way throughout the work. Aruz patterns corresponding to the unit values are as follows:

1. Ölçü

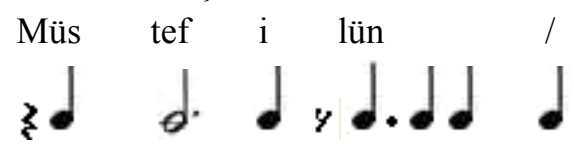

3. Meter

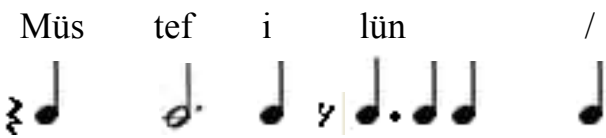

2. Meter

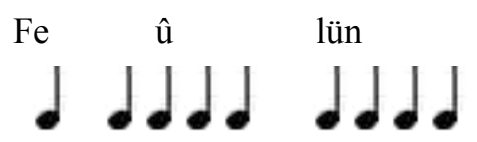

4. Meter

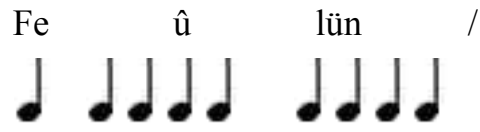

2-Examinations conducted based on Prosodic Patterns:

\section{Mef û lü/ Me fâ î lü/ Me fâ î lü/ Fe û lün Pattern}

Mef ûl lü/ Me fâ î lü/ Me fâ îlü/ Fe û lün pattern was used in works composed with 10-time Aksak Semai usul, 9-time Aksak usul, 6-time Yürük Semai usül and 5-time Türk Aksak usul as mentioned above.

Following is meter and unit value analysis of Murabba Ağır Semai in Hüzzam tune by Haci Faik Bey.

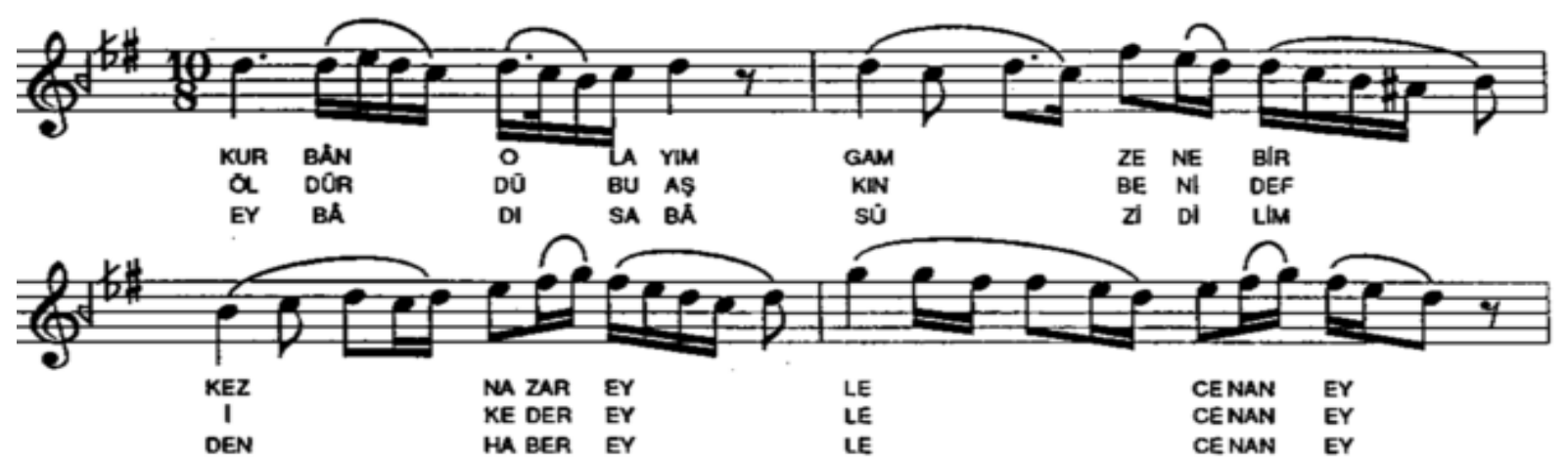

Kur bân o la yım gâm ze ne bir kez na za rey le

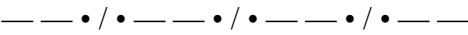

Mef û lü / Me fâ î lü / Me fâ î lü / Fe û lün 


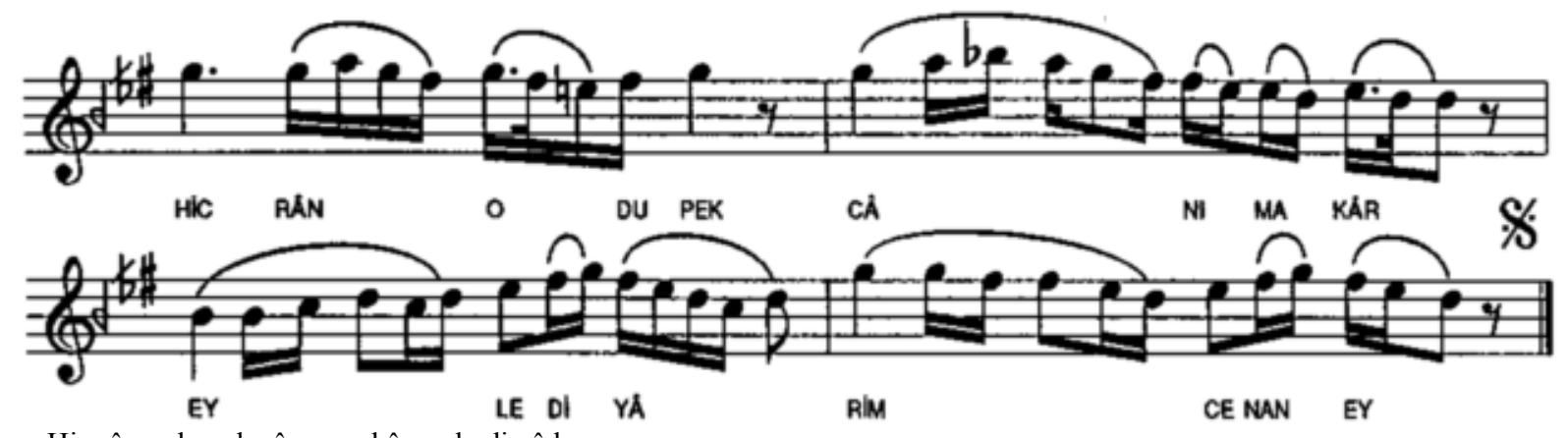

Hic rân o du pek câ nı ma kâr ey le di yâ le

—— $\bullet / \cdot \bullet-\ldots \cdot 1 \cdot \ldots \ldots \cdot / \cdot-\ldots$

Mef û lü / Me fâ î lü / Me fâ î lü / Fe û lün

The lyrics of this work consist of four verses, all verses were analyzed above. In the first example, one, two, and four verses and in the second example three verses are seen. As each verse is being completed in four meters, each prosodic pattern is completed in four meters. The same rhythm patterns are covered by the same rhythmic movements in verse four, rhythmic values taken by the prosodic patterns continue in the same way throughout the work. Following are the aruz patterns corresponding to the unit values.

1. Meter

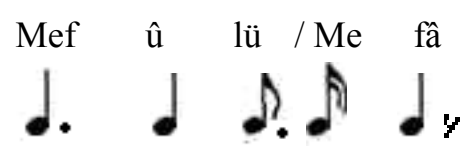

3. Meter

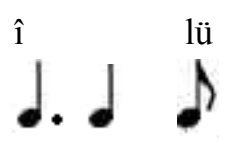

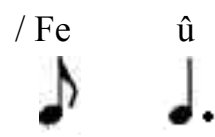

2. Meter

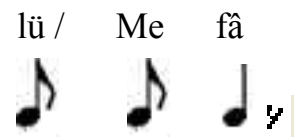

4. Meter

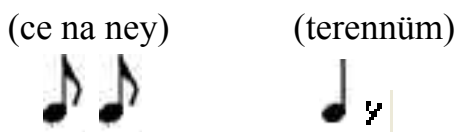

\section{Fâ i lâ tün/ Fâ i lâ tün/ Fâ i lün Kalıbı}

It has been observed that Fâ i 1 â tün/ Fâ i lâ tün/ Fâ i lün pattern was used in works composed with 28-time Devri Kebir usul, eight-time Müsemmen usul, and seven-time Devri Hindi usul.

Following is prosody, meter and unit value analysis of Suznâk Ağır Semai by Kucuk Mehmed Agha.
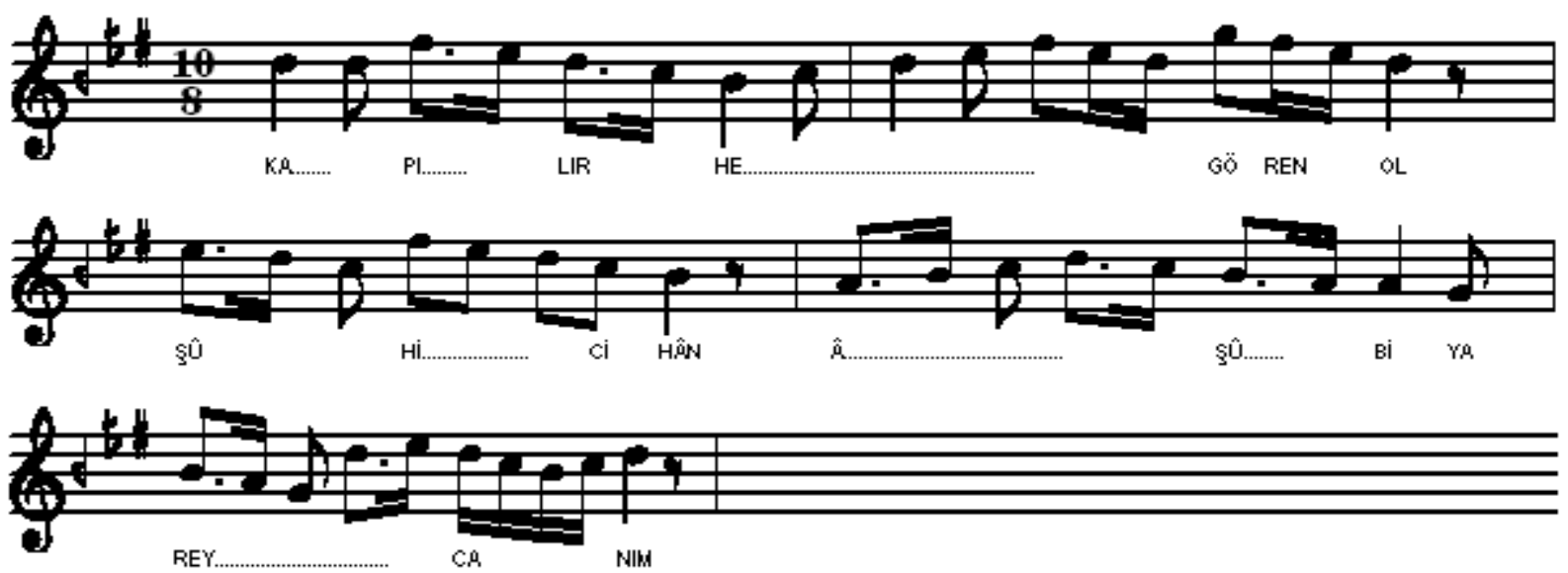

Kâ pı lır her gö re nol şûh i ci hân â şû bi

$-\bullet-\ldots-1 \cdot \cdots-1 \cdot-\ldots$

Fâ i lâ tün / Fe i lâ tün / Fe i lâ tün Fâ lün 

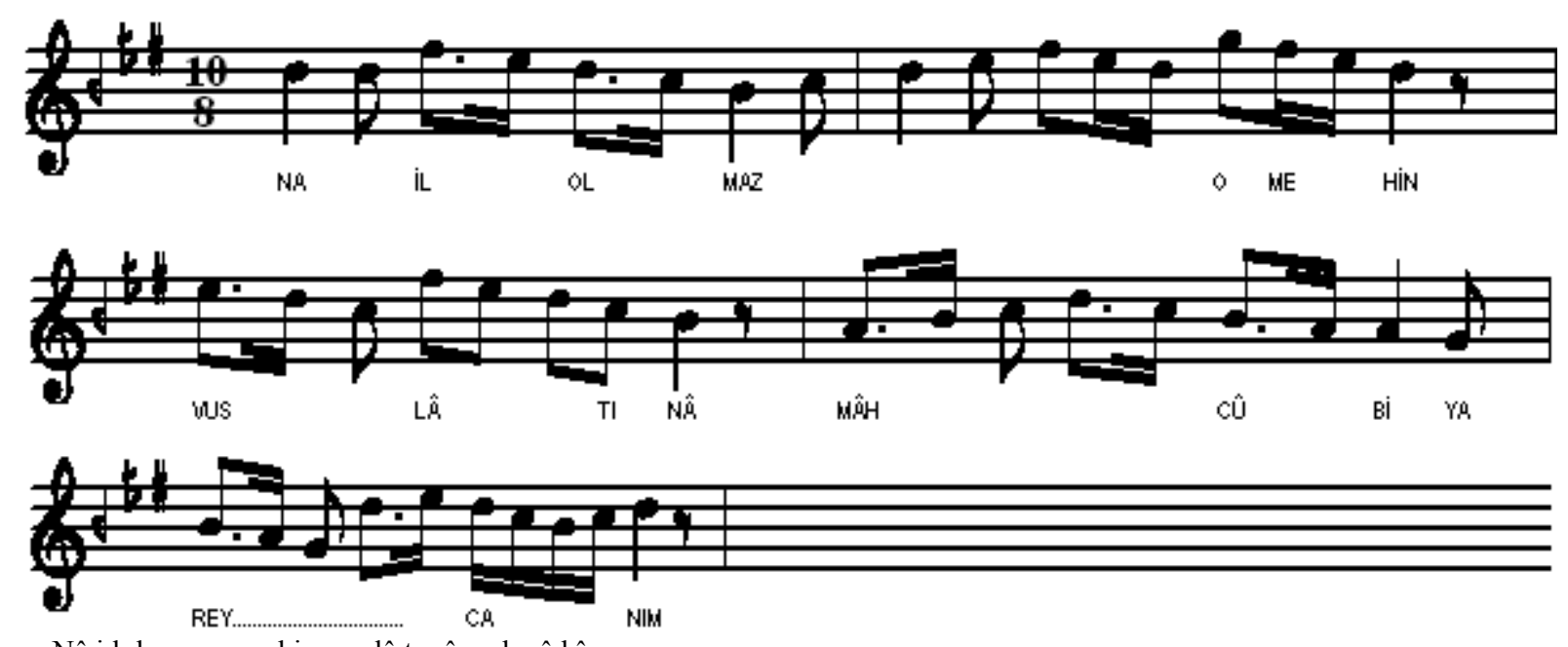

Nâ i lol maz o me hin vus lâ tı nâ mah cû bî

- - - - $1 \cdot \cdot-1-\cdot-1-\ldots$

Fâ i lâ tün / Fe i lâ tün / Fâ i lâ tün Fâ lün

The lyrics of this work consist of four verses. As each verse is being completed in five meters, each prosodic pattern is completed within five meters. The verses one and four are seen above. The same prosodic patterns are covered by the same rhythmic movements in four verses, rhythmic values taken by the prosodic patterns continue in the same way throughout the work. Aruz patterns corresponding to the unit values are as follows:

1. Öeter

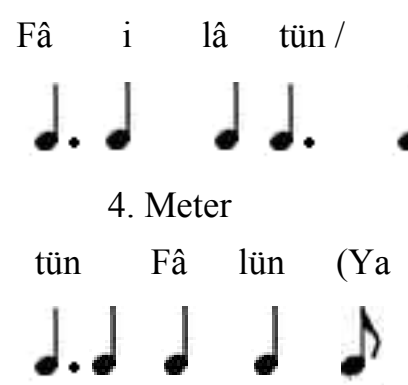

2. Meter

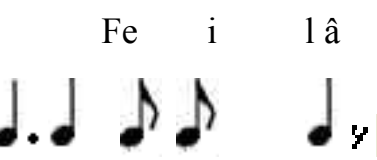

5. Meter

Below is the prosody, meter and unit value analysis of Beyati Şarkı by Mahmud Calaleddin Pasha.

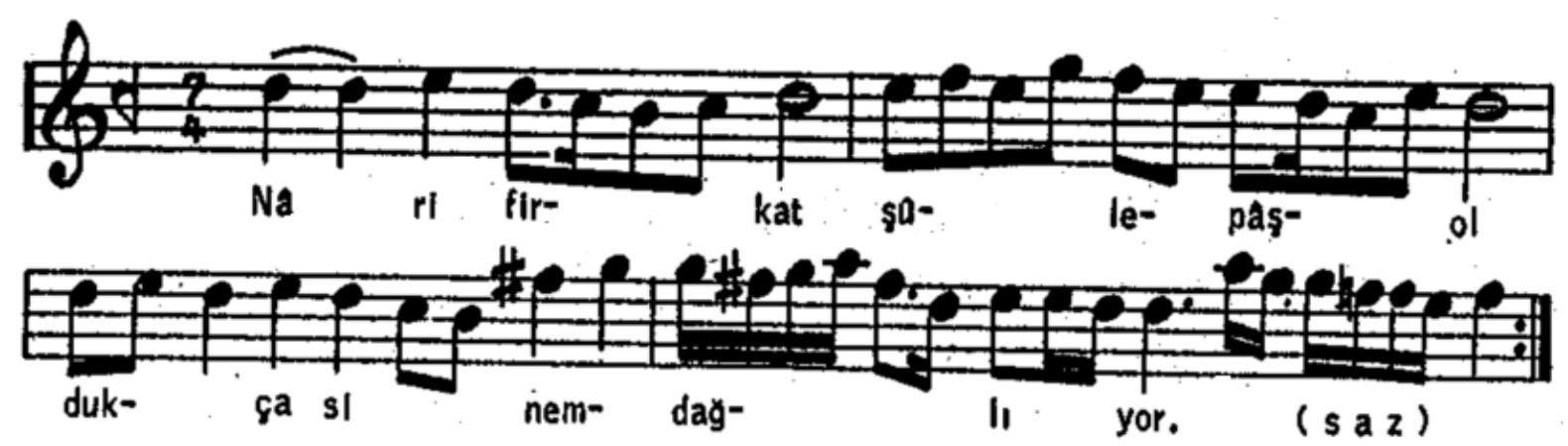

Nâr 1 fir kât / şû le pâş ol / duk ça sî nem / dağ li yor

$-\cdot-1-\cdot-1-\cdot-1-\cdot-$

Fâ i lâ tün / Fâ i lâ tün / Fâ i lâ tün Fâ i lün 


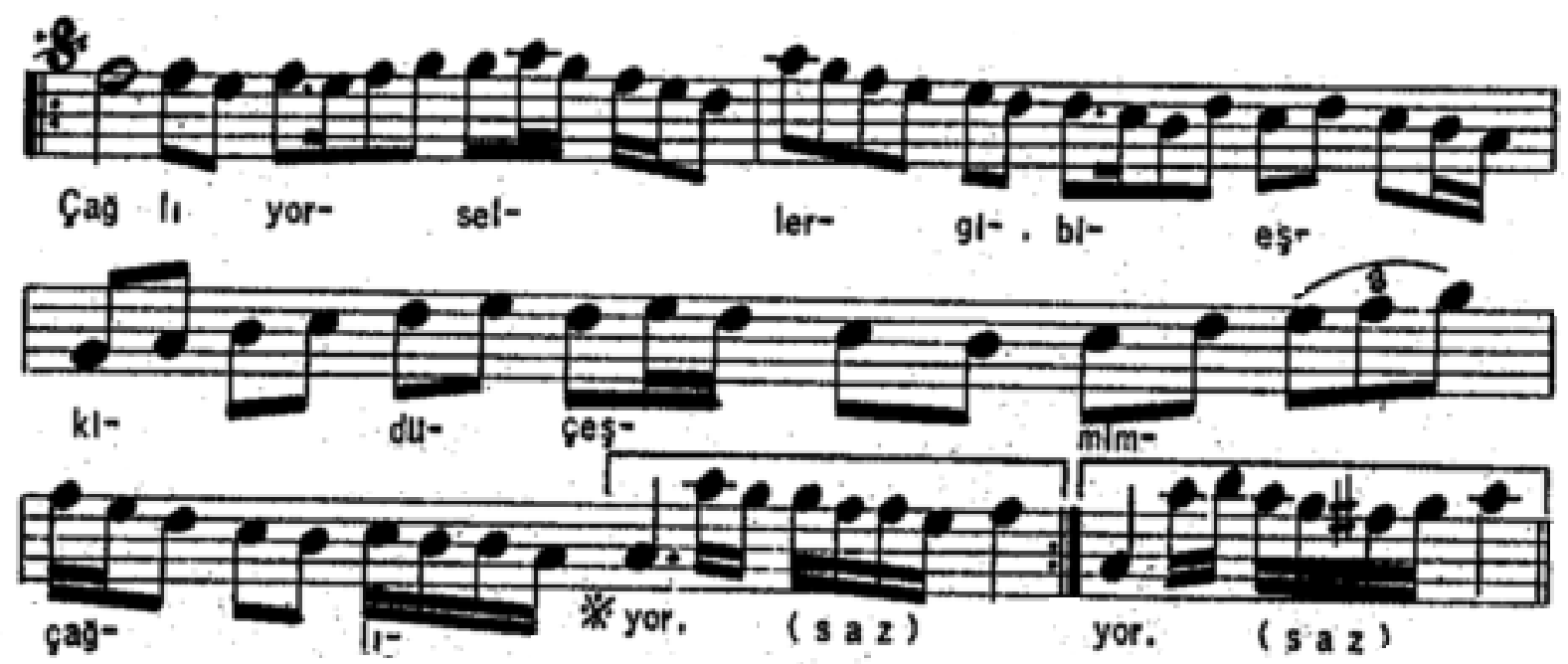

Çağ lı yor sel ler gi bi eş kî dü çeş mim çağ lı yor

Fâ i lâ tün / Fâ i lâ tün / Fâ i lâ tün Fâ i lün

The lyrics of this work consist of four verses. As each verse is completed in four meters, each prosodic pattern is completed in four meters. Prosodic patterns in each four verses start at the beginning of the meter and end at the end of the meter, same patterns are covered by the same rhythmic movements and rhythmic values of the patterns continue in the same way throughout the work. Aruz patterns corresponding to the unit values are as follows:
1. Meter
2. Meter
3. Meter
4. Meter
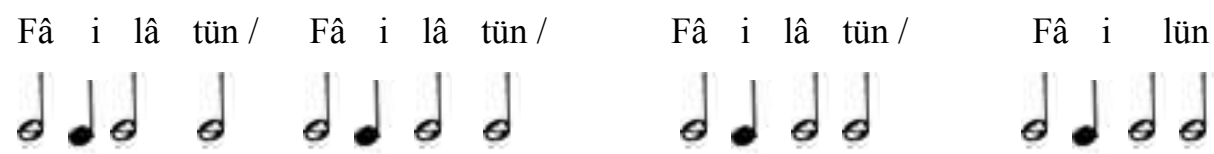

\section{Prosodic Harmony}

It appears that prosodic and usul patterns form the backbone of the work by combining in a balanced and harmonious way. This combination in the work refers to the harmony of prosody, usul, and melody called prosodic harmony.

Prosody comes from the Greek word "Prosodia" which is simply defined as "the science of the proper reading of the words observing the emphasis and length of syllables". If there is no deterioration in the anatomical structure of the word during the performance of a work, it is understood that work is in accordance with the rules of prosody (Hatipoğlu, 1983, p. 1).

In prosody, syllables ending in vowels open and short, consonants ending or ending with a vowel, syllables extended with hat off are defined as closed and long. In terms of the Poetic Prosodic Meter, the use of the sign • open syllables and the sign - for closed syllables indicates the common criteria between prosody and poetics.

In terms of music, short-open syllables are not suitable for extension and have no tolerance of being used outside of their values. Long-closed syllables are suitable for extension; however they have no tolerance for restriction of their minimum value (Hatipoğlu, 1983, p. 3). 
Therefore, the rule that the composers comply with (perhaps intentionally, perhaps unintentionally) is the largest and the smallest unit values of open and closed syllables. The division of the unit time in open-closed syllable in accordance with usul and prosody shows the prosodic harmony.

Unit time given to the syllable is seen below with a section of the song by Hafiz Yusuf Efendi. $\downarrow$ for open, the smallest and largest for close syllables were used and prosody and usul harmony were established in the work.
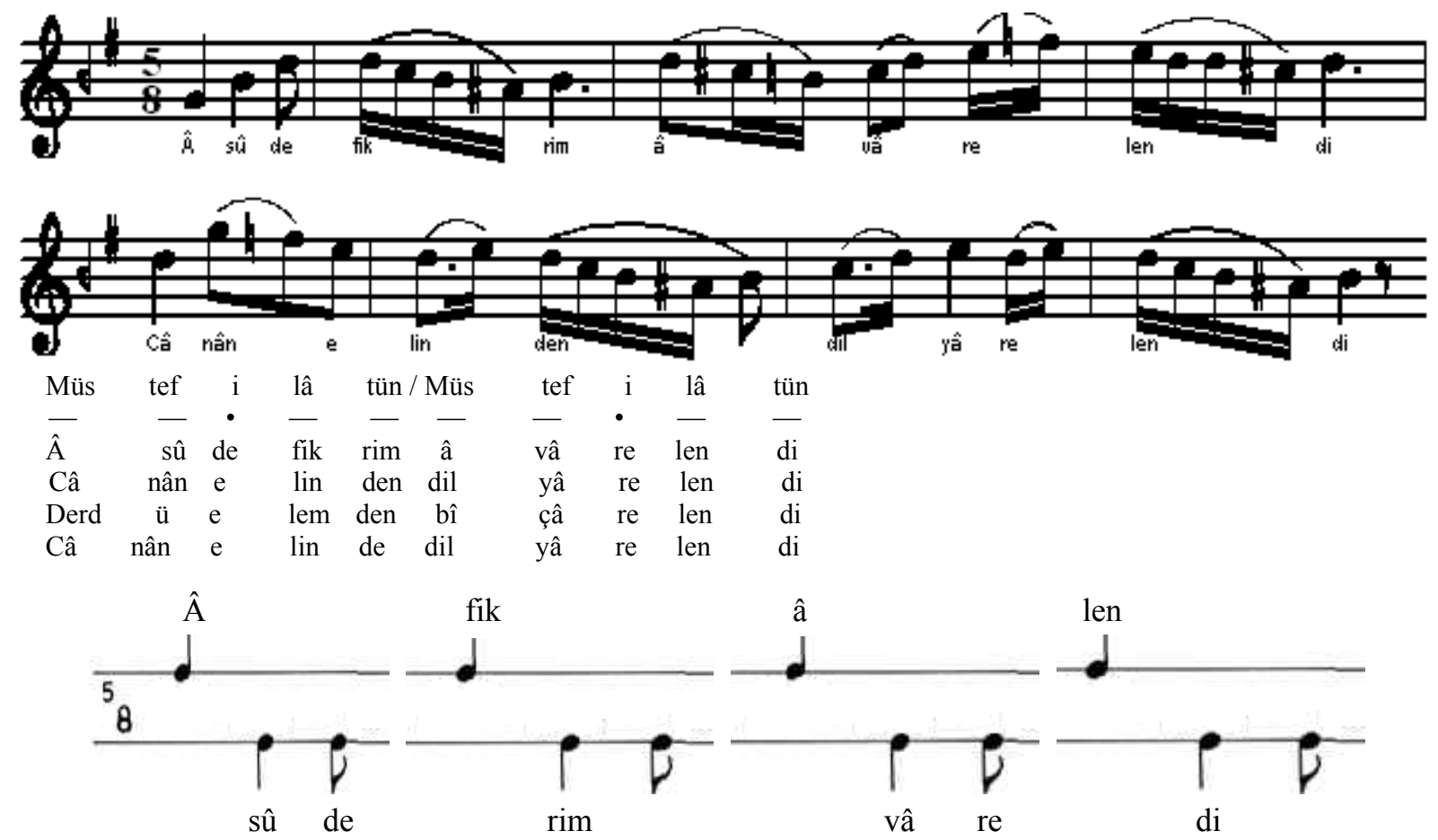

\section{Conclusion}

This paper discussed the relationship of melody-usul-aruz in the Ottoman-Turkish music and sample works have been examined in the context of prosody and usul patterns. Although frequently used prosodies and usuls were chosen, the number of such embodiments may be increased.

As a result of our study, it has been found out that there are specific usul patterns for each as well as there are prosodic patterns for each usul. In Ottoman Turkish Music, melody was added to the poetry within the framework of closed and open syllables, prosodic meter and usul darbs. Procedures, rhythm and volume of the divisions of time, internal and external rhythm of prosody pattern allow the conjugation of the work of internal and external rhythm. Therefore, every melody fragments, each tune, or every key necessarily correspond to certain parts of the usul and rhythm patterns. By usul patterns and process patterns that can hit people, it takes the melody and lyrics to memory, together with the region corresponding to the minting and memory is actually undertake the writing of his music.

Judging by the rhythm and style of all these features, writing the music and memory has refused numerous works by the method of transfer of a music traditions from generation to generation, which will not be wrong to say that this power and the rhythm method. Aruz consisting of usuls and patterns composed of rhythms is 
involved in the saving of the work into the memory. Therefore, aruz and usul live almost in the work.

Although the aruz prosody was replaced by syllable and free prosody, there are poets and composers who use this kind of meter. We believe that all the features of aruz mentioned above - the existence in the tradition of Ottoman-Turkish music, a method that conveys ancient memory to the present and the backbone of the work alongside with usul - are the most important reason for taking it to further generations.

\section{References}

Behar, C. (1992). Time, space and music. Istanbul: Afa Publications.

Hatipoğlu, A. (1983). Comparative and applied Turkish music prosody. Ankara, Turkey: TRT Music Department Publications. Heper, G. (1997). Türk Aksağı Usulünde Yazılmış Eserlerin vezin-Usul İlişkisi (Unpublished Thesis, Istanbul Technical University Turkish Music State Conservatory, Department of Basic Sciences).

Meydan, L. (1969). Aruz prosody. Istanbul: Meydan Publishing House.

Özcan, N. (1997). Music in XV and XVI. Centuries Turkish World and the Turkish values of the XV and XVI (pp. 471-483). Centuries.

Pekin, N., \& Karaman, N. (1982). Literature information. Istanbul: Minnetoğlu Publications.

Ungay, H. (1981). Usul and Kudüm in Turkish music. Istanbul: Turkish Music Foundation. 